\title{
The Difference in Maternal Serum Hypoxia-Inducible Factors-1 $\alpha$ Levels between Early Onset and Late-Onset Preeclampsia
}

\author{
Roza Sriyanti ${ }^{1,2^{\star}}$, Johanes C. Mose ${ }^{3}$, Masrul Masrul ${ }^{4}$, Netti Suharti $^{5}$ \\ ${ }^{1}$ Postgraduate Biomedical Science, Faculty of Medicine, Andalas University, Padang, Indonesia; ${ }^{2}$ Division of Maternal-Fetal \\ Medicine, Department of Obstetrics and Gynecology, Faculty of Medicine, Andalas University, Dr M. Djamil Central General \\ Hospital, Padang, Indonesia; ${ }^{3}$ Division of Maternal-Fetal Medicine, Department of Obstetrics and Gynecology, Faculty of \\ Medicine, Padjadjaran University, Hasan Sadikin Bandung, Indonesia; ${ }^{4}$ Department of Nutrition, Faculty of Medicine, \\ Andalas University, Padang, Indonesia; ${ }^{5}$ Department of Microbiology, Faculty of Medicine, Andalas University, Padang, \\ Indonesia
}

Citation: Sriyanti R, Mose JC, Masrul M, Suharti N. The Difference in Maternal Serum Hypoxia-Inducible Factors-
$1 a$ Levels between Early Onset and Late-Onset Preeclampsia. Open Access Maced J Med Sci. 2019 Ju 15; https://doi.org/10.3889/oamjms.2019.601 Keywords: HIF-1a levels; Preeclampsia onset; Pregnancy

*Correspondence: Roza Sriyanti. Postgraduate Biomedical Science, Faculty of Medicine, Andalas University, Padang, Indonesia. E-mail: roza.sriyanti@yahoo.com

Received: 07-Apr-2019; Revised: 14-Jul-2019; Accepted: 15-Jul-2019; Online first: 13-Jul-2019

Copyright: () 2019 Roza Sriyanti, Johanes C. Mose, article distributed under the terms of the Creative Commons Attribution-NonCommercial 4.0 Internationa License (CC BY-NC 4.0)

Funding: This research did not receive any financia support

Competing Interests: The authors have declared that no competing interests exist

\begin{abstract}
BACKGROUND: Preeclampsia can be divided into early (EOPE) and late (LOPE) onset preeclampsia. Preeclampsia is related to the failure of placentation. Accumulation of hypoxia-inducible factors (HIF)-1a is commonly an acute and beneficial respond to hypoxia, while chronically elevated is associated with preeclampsia.

AIM: This study aims to evaluate the serum levels of HIF-1 $\alpha$ in preeclampsia and normal pregnancy, and to compare the difference between early-onset and late-onset preeclampsia.

METHODS: A cross-sectional comparative study was conducted among a total of 69 pregnant women at $\geq 20$ weeks of gestation, were recruited at obstetrics and gynaecology department at Dr M. Djamil Padang Hospital, network hospitals, health centres. They were divided into three groups early-onset preeclampsia, late-onset preeclampsia, and normal pregnancy. Preeclampsia was diagnosed using International Guidelines. Data were analysed by SPSS 24 program; data are presented as median and range or as mean \pm standard deviation. Oneway ANOVA test was used to determine the relationship between HIF-1 $\alpha$ levels with the onset of preeclampsia.

RESULTS: The results showed that the mean maternal serum HIF-1 $\alpha$ levels in early-onset preeclampsia (EOPE), late-onset preeclampsia (LOPE), and normal pregnancy were $1366.96 \pm 733.40 \mathrm{pg} / \mathrm{ml}, 916.87 \pm 466.06 \mathrm{pg} / \mathrm{ml}$, and $716.77 \pm 541.08 \mathrm{pg} / \mathrm{ml}$. Serum HIF-1a levels were higher in early-onset preeclampsia (EOPE), and late-onset preeclampsia (LOPE) compared to normal pregnancy. Among preeclampsia patients, serum HIF-1 $\alpha$ was higher in EOPE than LOPE women. Statistical analysis revealed a significant difference in mean maternal serum HIF-1a between early-onset preeclampsia, late-onset preeclampsia, and normal pregnancy $(p<0.05)$.
\end{abstract}

CONCLUSION: This study concluded that there is a significantly different level of HIF-1 $\alpha$ between in early-onset preeclampsia, late-onset preeclampsia and normal pregnancy. Early-onset preeclampsia is the highest levels of serum HIF-1a.

\section{Introduction}

Preeclampsia is a multisystem disorder that occurs in about $2-10 \%$ of all pregnancies and most often causes maternal and fetal morbidity and mortality [1], [2]. The World Health Organization (WHO) reports $16 \%$ of maternal mortality caused by preeclampsia in developing countries [3]. Preeclampsia can be divided into sub-classifications: early-onset preeclampsia (EOPE) and late-onset preeclampsia (LOPE). The risk of maternal and fetal mortality in early-onset preeclampsia (EOPE) is significantly greater than that of late-onset preeclampsia (LOPE), this is due to the large majority of problems with severe placental perfusion and prematurity [4]. Most newborns from EOPE pregnancies experience premature and fetal growth restriction (FGR) [5], [6].

Based on the research which is placenta molecular basically, EOPE has oxygen level more than LOPE. Van der Merwe et al., (2010) report that placenta of EOPE is smaller has more infarct, and 
unexact maturation, meanwhile placenta of LOPE has enhancement of decidual arteriopathy and placental solution [7].

EOPE occurs in $5-20 \%$ of all cases of preeclampsia associated with impaired fetal growth, pathological fetus, impaired uterine blood circulation, small placental size, preterm birth, and neonatal mortality whereas LOPE is around $75-80 \%$ of the total cases of preeclampsia associated with maternal mobility (such as metabolic syndrome, impaired glucose tolerance, obesity, dyslipidemia, chronic hypertension), with normal fetal weight and normal placental volume [7]. Although the aetiology of preeclampsia is unclear, abnormalities in the placenta are undoubtedly the pathogenesis of preeclampsia. The presence of abnormal placentations, including incomplete trophoblast spiral arteries invasion, plays an important role as the pathogenesis and pathophysiology of preeclampsia [1], [8].

Preeclampsia is related with failure of placentation, which is begin by the failure of arterial spiralis remodelling to the place of implantation. The pathological change of preeclampsia signed bg antiangiogenesis, hypoxia, endosteal dysfunction, and interference of immunology's response, which cause disturbance of morphology and histopathology of many organs such as heart, lung, kidney, heart, brain and placenta [9].

Accumulation of hypoxia-inducible factor 1 a (HIF-1 $\alpha$ ) is commonly an acute and beneficial respond to hypoxia, while chronically elevated HIF-1a is associated with multiple disease conditions, including preeclampsia [10].

The initial phase of placentation happened under the relative hypoxia condition. HIF-1a as the marker of the cellular oxygen deprivation, expressed by its high level in the trophoblast. Persistent hypoxia or the failure to decrease the expression of transforming growth factor $\beta 3$ (TGF- $\beta 3$ ) after the ninth month of the pregnancy cause failure of trophoblast to differentiate from proliferative phenotype become invasive. The expression of HIF-1a is regulated not only by hypoxia but also by inflammation stimulation (for example, thrombin, peptide cytokine, like tumour necrosis factor (TNF), and reactive oxygen species (ROS), especially mediated by nuclear factor KB (NF$\mathrm{KB})$, as the promotor of HIF-1 $\alpha$ contains binding site of NF-KB [9].

The availability of oxygen greatly influences placental function at all stages of pregnancy, and hypoxia-inducible factors (HIF) are the main mediator of placental adaptation [11]. During hypoxia, HIFs are stabilised and act as transcription factors [12]. During low oxygen conditions, HIF-1a is expressed high and helps placental development early in pregnancy. Excessive expression of HIF-1a has been observed in many inflammatory disorders, including cancer and preeclampsia [13].
The role of HIF-1a in the pathogenesis of preeclampsia is evidenced by Cannigia et al., (2000) which shows that HIF-1a is expressed more by the placenta with a low oxygen condition at initial gestation, then decreases at week 9 gestational age when oxygen levels begin to increase [14]. Likewise, with the research of Rajakumar et al., (2000) which states that HIF-1a plays an important role in the development and function of the placenta [15], [16]. Bobek et al. (2015) also researched mice and found that HIF-1 $\alpha$ induced by cytokine imbalance, plays a role in the pathogenesis of preeclampsia [17]. Another study by Akhilesh et al. (2013) proves that HIF-1a levels in preeclampsia women are higher than controls [18].

Research on the relationship of HIF-1a levels in preeclampsia, especially in EOPE, where there is still not much research done, and the results are still controversial. The goals of this study were to evaluated the serum levels of HIF-1a in preeclampsia and normal pregnancy and to compare the difference between early-onset and late-onset preeclampsia.

\section{Material and Method}

\section{Subjects}

The study was conducted at Dr M. Djamil Hospital Padang, network hospitals and health centres. The study used a cross-sectional comparative study design by comparing the three study groups, namely early-onset preeclampsia, lateonset preeclampsia, and normal pregnancy to evaluated the serum levels of HIF-1a in preeclampsia and normal pregnancy and to compare the difference between early-onset and late-onset preeclampsia. Preeclampsia is defined as hypertension with minimum criteria for systolic blood pressure $\geq 140$ $\mathrm{mmHg}$ and/or diastolic blood pressure $\geq 90 \mathrm{mmHg}$ after 20 weeks' gestation, and one or more proteinuria $\geq 300 \mathrm{mg} / 24$ hours or urine / creatinine protein ratio $\geq 30 \mathrm{mg} / \mathrm{dl}$ (1 + urine dipstick), renal insufficiency, hematological abnormalities, liver disorders, cerebral disorders, pulmonary edema. The number of samples was 69 samples that met the inclusion criteria (single pregnancy women, gestational age $>20$ weeks, there were no severe medical abnormalities, no chorioamnionitis and no pregnancy with major congenital abnormalities), and exclusion criteria damage to blood samples during the research process and patients drop out during the research process). The study was conducted at Dr M. Djamil Padang Hospital, network hospitals and health centres. In patients who come in the third trimester, into the late-onset sample because sampling is done when the patient first arrives. 


\section{Samples}

Patients who meet the inclusion and exclusion criteria will be interviewed to obtain characteristic data including name, age, identity number, address, contact number, history of pregnancy, the first day of the last day or ultrasound examination to assess gestational age. The size of the samples is calculated according to the simple formula to estimate the proportion of a population. The sampling formula used in unpaired numerical comparative research [19]. The sampling technique is done by the consecutive method, i.e. the samples are taken sequentially. By the inclusion criteria and exclusion until the required number of samples is fulfilled. After the patient signed a letter of informed consent, venous blood specimens were collected in the median cubital vein by folding the elbow by $10 \mathrm{ml}$. Next blood is sent to the laboratory for examination HIF-1a levels. Examination of HIF-1a levels using reagents from the Human Hypoxia Inducible Factor-1a ELISA Kit (Catalog No: E-EL-H1277, R \& D System, USA). How to measure BMI before pregnancy is by asking the patient the weight and height of the patient before the detection of pregnancy. In this study, patients were not followed up until birth. This baby weight data is obtained from secondary data available.

\section{Examination of HIF-1a Levels (Work protocol based on the Human HIF-1a ELISA Kit)}

Prepare all reagents and samples at the examination room temperature. Add $100 \mathrm{ul}$, blank and sample into each well. Add 100 ul Biotinylated Detection Abworking solution into each well, cover with plate sealer. One-hour incubation at $37^{\circ} \mathrm{C}$. Dispose of all fluids in the well. Wash well by adding $350 \mathrm{ul}$ of wash buffer solution. Repeat three items of washing. Add 100 ul Avidin-Horseradish Peroxidase (HRP) Conjugate working solution to all wells. Cover with plate sealer. Incubate for 30 minutes at $37^{\circ} \mathrm{C}$. Repeat the washing process as in step 5 five times. Add 90 ul of the Substrate Reagent solution to each well. Cover with a new plate sealer. Incubation for 15 minutes at $37^{\circ} \mathrm{C}$. Avoid bright light. Add 50 ul Stop Solution to each well. Read the results of the inspection with the ELISA reader at a wavelength of $450 \mathrm{~nm}$. Optical density (OD) values and concentration values of samples were examined.

\section{Statistical Analysis}

Data were analysed by SPSS 24 program; data are presented as median and range or as mean \pm standard deviation. One-way ANOVA test was used to evaluate the serum levels of HIF-1a in preeclampsia and normal pregnancy, and to compare the difference between early-onset and late-onset preeclampsia, if a $p$-value of $<0.05$ was obtained, a significant association was found HIF-1a levels with the onset of preeclampsia.

\section{Results}

The study was conducted on 69 patients consisting of 23 early-onset preeclampsia, 23 lateonset preeclampsia and 23 normal pregnancies. Sample characteristic of 69 patients, based on age, gestational age, parity, systole and diastole blood pressure, body mass index (BMI), and birth weight was shown in Table 1.

Table 1: Clinical characteristics of the study population

\begin{tabular}{lccc}
\hline Characteristic & EOPE $(\mathrm{n}=23)$ & $\mathrm{LOPE}(\mathrm{n}=23)$ & Normal $(\mathrm{n}=23)$ \\
\hline Age of pregnant women (year) & $32.35 \pm 7.33$ & $32.96 \pm 6.8$ & $29.30 \pm 2.18$ \\
Gestational age (week) & $29.04 \pm 3.37$ & $36.91 \pm 2.04$ & $38.22 \pm 0.67$ \\
$\begin{array}{l}\text { Parity (\%) } \\
-\quad \text { Nullipara }\end{array}$ & 34.8 & & \\
$-\quad$ Multipara & 65.2 & 39.1 & 4.3 \\
Systolic blood pressure $(\mathrm{mmHg})$ & $169.35 \pm 20.90$ & $160.43 \pm 17.18$ & $114.78 \pm 5.11$ \\
Diastolic blood pressure $(\mathrm{mmHg})$ & $103.61 \pm 12.32$ & $100 \pm 9.53$ & $73.48 \pm 4.87$ \\
BMl before pregnancy $\left(\mathrm{kg} / \mathrm{m}^{2}\right)$ & $28.52 \pm 5.06$ & $28.76 \pm 6.04$ & $25.08 \pm 1.69$ \\
BMl during pregnancy $\left(\mathrm{kg} / \mathrm{m}^{2}\right)$ & $32.18 \pm 4.84$ & $35.10 \pm 6.56$ & $31.02 \pm 1.96$ \\
Birth weight $(\mathrm{gr})$ & $1363.48 \pm 486.58$ & $2945.00 \pm 675.76$ & $2730.43 \pm 186.92$ \\
\hline
\end{tabular}

Based on the table, it is known that earlyonset and late-onset preeclampsia have respondents with almost the same age, namely 32 years, whereas in normal pregnancies the average age is 29 years. In the early onset preeclampsia group, the systolic blood pressure is higher than the late-onset preeclampsia and normal pregnancy $(169.35 \pm 20.90 \mathrm{mmHg}$ vs $160.43 \pm 17.18 \mathrm{mmHg}$ vs $114.78 \pm 5.11 \mathrm{mmHg}$ ). Likewise, with diastole blood pressure found in the preeclampsia group, early onset is higher than lateonset preeclampsia and normal pregnancy $(103.61 \pm$ $12.32 \mathrm{mmHg}$ vs $100 \pm 9.53 \mathrm{mmHg}$ vs $73.48 \pm 4.87$ $\mathrm{mmHg}$ ). In the late-onset preeclampsia group, the mean IMT before pregnancy was higher than that of early-onset and normal pregnancy $(28.76 \pm 6.04$ $\mathrm{kg} / \mathrm{m}^{2}$ vs $28.52 \pm 5.06 \mathrm{~kg} / \mathrm{m}^{2}$ vs $25.08 \pm 1.69 \mathrm{~kg} / \mathrm{m}^{2}$ ). Similar results were found in IMT during pregnancy $\left(35.10 \pm 6.56 \mathrm{~kg} / \mathrm{m}^{2}\right.$ vs $32.18 \pm 4.84 \mathrm{~kg} / \mathrm{m}^{2}$ vs $31.02 \pm$ $\left.1.96 \mathrm{~kg} / \mathrm{m}^{2}\right)$.

Table 2: HIF-1 $\alpha$ levels and the onset of preeclampsia

\begin{tabular}{lllll}
\hline Variable & \multicolumn{2}{l}{ Preeclampsia Onset } & P-value \\
& EOPE $(n=23)$ & LOPE $(n=23)$ & Normal $(n=23)$ & \\
\hline HIF-1 $(\mathrm{pg} / \mathrm{ml})$ & $1366.96 \pm 733.40$ & $916.87 \pm 466.06$ & $716.77 \pm 541.08$ & 0.003 \\
\hline
\end{tabular}

As described in Table 2, there was the difference in maternal serum HIF-1a between groups early-onset preeclampsia, late-onset preeclampsia, and normal pregnancy, in which the mean level of maternal HIF-1 $\alpha$ was $1366.96 \pm 733.40 \mathrm{pg} / \mathrm{ml}, 916.87$ $\pm 466.06 \mathrm{pg} / \mathrm{ml}$ and $716.77 \pm 541.08 \mathrm{pg} / \mathrm{ml}$. The mean of maternal HIF-1a level was statistically different between early-onset preeclampsia, late-onset preeclampsia and normal pregnancy ( $p$-value $<0.05$ ). There is a significant difference between the levels of HIF-1 $1 \alpha$ and the onset of preeclampsia, as shown in Figure 1. 


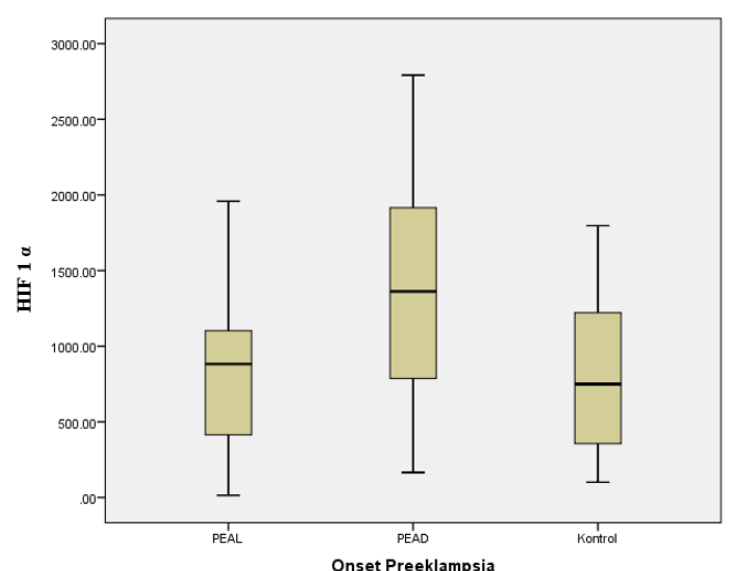

Figure 1: Boxplot Levels of HIF-1a with the Onset of Preeclampsia

From Figure 1, it is known that HIF-1a levels are higher in early-onset preeclampsia than late-onset preeclampsia and normal pregnancy.

\section{Discussion}

Although the aetiology of preeclampsia is unclear, abnormalities in the placenta are undoubtedly the pathogenesis of preeclampsia [1], [8]. Accumulation of hypoxia-inducible factor $1 \alpha$ (HIF-1a is commonly an acute and beneficial respond to hypoxia, while chronically elevated HIF-1a is associated with multiple disease conditions, including preeclampsia [10].

The results of this study showed that the mean HIF-1a levels were significantly higher in both preeclampsia groups (early-onset and late-onset) compared to the normal pregnancy. Statistically, there is a significant difference with a value of $p 0.003(p<$ 0.05 ) between levels of HIF-1a and the onset of preeclampsia. Whereas research conducted by Rath et al., (2014) obtained ROC curve analysis, HIF-1a nucleus expression was significant in the preeclampsia group compared to the control group $(\mathrm{P}$ $=0.0001$ ) with $88.9 \%$ specificity and $88.9 \%$ sensitivity, whereas ELISA obtained HIF-1 $\alpha$ serum levels higher (mean $=6,581 \mathrm{pg} / \mathrm{ml}$ ) in the preeclampsia group than in the control group (mean $=4,947 \mathrm{pg} / \mathrm{ml}$ ) [13]. Kimura et al., (2012) measuring the proportion of positive nuclei of HIF-1a in placental trophoblast cells and found that staining of HIF-1 $\alpha$ was significantly higher in both groups of preeclampsia than in the control group. However, the more staining was observed in women with early-onset preeclampsia compared to women with late-onset preeclampsia [20]. HIF-1 $\alpha$ is a major transducer of hypoxic signals in several tissues, including the human placenta. HIF-1a is very highly expressed in low oxygen environments in early pregnancy and plays an important role in the development and function of the placenta. HIF-1 $\alpha$ also shows overexpression in the placenta of preeclamptic women, together with soluble Fms-like tyrosine kinase-1 (sFlt-1) and soluble endoglin (SEng) [21]. HIF-1 was transcripted by much dependent oxygen genes that code protein, which correlates to angiogenesis and cell metabolism [13]. HIF-1a plays a role in maintaining homeostatic state, inducing gene transcription such as VEGF and erythropoietin. When the level of oxygen is low, HIF-1a would express much more and helps placenta development on early pregnancies. Chaiworapongsa et al., (2014), considerable evidence supports a role for hypoxia in creating an environment that predisposes to implantation disorders, including preeclampsia: expression of HIF-1 $\alpha$ and HIF-2 $\alpha$ protein is increased in the placentas of women with pre-eclampsia [9]. During low oxygen conditions, HIF-1a is expressed high and helps placental development early in pregnancy. Excessive expression of HIF-1 $\alpha$ has been observed in many inflammatory disorders, including cancer and preeclampsia [13]. This theory matches Rajakumar et al., (2003) that preeclampsia placenta got more over the expression of HIF-1 $\alpha$ and HIF-2 $\alpha$ compared to the normal placenta. Even explant villus oxygenation from preeclampsia placenta failed to lower HIF-1 $\alpha$ and HIF-2 $\alpha$ levels in vitro [15].

In this study it was found that HIF-1a levels were higher in EOPE than others, similar to the theory that the key mediator of this hypoxic condition is HIF$1 \alpha$. HIF-1a is included in the description by many dependent oxygen genes that encode proteins that are associated with angiogenesis and cell metabolism [13], [22]. Likewise, with research conducted by Roflo et al., (2010), it was found that oxygen disorders occur in placenta EOPE, but not in placental LOPE [21]. Hypoxic conditions affect HIF-1a levels. HIF-1a is the main mediator, which is the cellular response to oxygen pressure under pathological and physiological conditions. Other researchers also proved that HIF-1a levels in preeclampsia women were higher than controls [18]. However, it is different from the study by Davutoglu et al., (2017) which found no significant difference between HIF-1 $\alpha$ levels in preeclampsia and control, and found that HIF-1 $\alpha$ levels were greater in LOPE. They suspect that the mechanism of inflammation and independent oxygen is the dominant form of increasing HIF-1 $\alpha$ in late-onset preeclampsia [22].

In the condition of early-onset preeclampsia that last a long time, uterine artery blood flow is damaged, and the reduction in placental blood flow and the severity of hypoxic changes and DNA oxidation damage is greater in the placenta, causing fetal growth restriction (FGR), therefore most women preeclampsia with FGR experiencing preeclampsia early-onset and inadequate trophoblast cell invasion and remodelling of incomplete spiral arteries often occur in early-onset preeclampsia women [20].

There are a significant difference level of HIF$1 \alpha$ between in early-onset preeclampsia, late-onset 
preeclampsia and normal pregnancy. Early-onset preeclampsia is the highest levels of serum HIF-1 $\alpha$.

\section{References}

1. Rigo J, Szendei G, Rosta K, et al. Leptin receptor gene polymorphisms in severe preeclampsia women. Gynecological Endocrinology. 2006; 22(9):521-525. https://doi.org/10.1080/01674820600915502 PMid:17071538

2. Salimi S, Mashhadi FF, Naghavi A, et al. Different profile of serum leptin between early onset and late onset preeclampsia. Hindawi Publishing Corporation Disease Markers. 2014; 2014:1-7 https://doi.org/10.1155/2014/628476 PMid:24591763

PMCid:PMC3925616

3. Cunningham FG, et al. Hypetensive disorder in pregnancy. Dalam William Obstetric 23 ed. New York: McGraw-Hill Companies Inc., 2014.

4. MacKay AP, Berg CJ, Atrash HK. Pregnancy-related mortality from preeclampsia and eclampsia. ObstetGynecol. 2001; 97(4):533-538. https://doi.org/10.1097/00006250-20010400000011 PMid:11275024

5. Von Dadelszen P, Magee LA, Roberts JM. Subclassification of preeclampsia. Hypertens pregnancy. 2003; 22(2):143-148. https://doi.org/10.1081/PRG-120021060 PMid:12908998

6. Ogge G, Chaiworapongsa T, Romero R, et al. Placental lesions associated with maternal underperfusion are more frequent in early onset than late onset preeclampsia. Journal of Perinatal Medicine. 2011; 3(6):641-652. https://doi.org/10.1515/ipm.2011.098 PMid:21848483 PMCid:PMC3213694

7. Van der Merwe JL, Hall DR, Wright C, Schubert P, Grove D. Are early and late preeclampsia distinct subclasses of the disease-what does the placenta reveal?. Hypertension in pregnancy. 2010; 29:457-467. https://doi.org/10.3109/10641950903572282 PMid:20701467

8. Roberts J. Pregnancy related hypertension. In (Creasy R, Resnik R, lams JD, editors) maternal-fetal medicine: principles and practice 6. Philadelphia: Saunders Elsevier, 2009:650-88. https://doi.org/10.1016/B978-1-4160-4224-2.50038-7 PMid:19486768

9. Chaiworapongsa T, Chaemsaithong P, Yeo L, Romero R. Preeclampsia part 1: current understanding of its pathophysiology Nature Reviews Nephrology. 2014; 10(8):466. https://doi.org/10.1038/nrneph.2014.102 PMid:25003615 PMCid:PMC5893150

10. Iriyama $T$, Wang W, Parchim NF, et al. Hypoxia -independent up regulation of placental HIF-1 $\alpha$ gene expression contributes to the pathogenesis of preeclampsia. Hypertension. 2015;

65(6):1307-1315

https://doi.org/10.1161/HYPERTENSIONAHA.115.05314 PMid:25847948 PMCid:PMC4859813

11. Adelman DM, Gertsenstein M, Nagy A, Simon MC, Maltepe E. Placental cell fates are regulated in vivo by HIF-mediated hypoxia responses. Genes \& development. 2000; 14(24):3191-203. https://doi.org/10.1101/gad.853700 PMid:11124810
12. Semenza GL, Agani F, Booth G, Forsythe J, lyer N, Jiang BH, Leung $S$, Roe R, Wiener $C, Y u$ A. Structural and functional analysis of hypoxia-inducible factor 1 . Kidney international. 1997; 51(2):5535. https://doi.org/10.1038/ki.1997.77 PMid:9027737

13. Rath G, Aggarwal R, Jawanjal P, Tripathi R, Batra A. HIF-1 Alpha and Placental Growth Factor in Pregnancies Complicated With Preeclampsia: A Qualitative and Quantitative Analysis. Journal of clinical laboratory analysis. 2016; 30(1):75-83. https://doi.org/10.1002/icla.21819 PMid:25545166

14. Caniggia I, Winter J, Lye SJ, Post M. Oxygen and placental development during the first trimester: implications for the pathophysiology of pre-eclampsia. Placenta. 2000; 21:S25-30. https://doi.org/10.1053/plac.1999.0522

15. Rajakumar A, Conrad KP. Expression, ontogeny, and regulation of hypoxia-inducible transcription factors in the human placenta. Biology of reproduction. 2000; 63(2):559-69. https://doi.org/10.1095/biolreprod63.2.559 PMid:10906065

16. Tal $R$. The role of hypoxia and hypoxia-inducible factor-1alpha in preeclampsia pathogenesis. Biology of reproduction. 2012; 87(6):1-8. https://doi.org/10.1095/biolreprod.112.102723 PMid:23034156

17. Bobek G, Surmon L, Mirabito KM, Makris A, Hennessy A. Placental Regulation of Inflammation and Hypoxia after TNF- $\alpha$ Infusion in Mice. American Journal of Reproductive Immunology. 2015; 74(5):407-18. https://doi.org/10.1111/aji.12417 PMid:26220019

18. Akhilesh M, Mahalingam V, Nalliah S, Ali RM, Ganesalingam $M$, Haleagrahara N. Hypoxia-inducible factor-1 $\alpha$ as a predictive marker in pre-eclampsia. Biomedical reports. 2013; 1(2):257-8. https://doi.org/10.3892/br.2012.44 PMid:24648931 PMCid:PMC3956219

19. Akhilesh M, Mahalingam V, Nalliah S, Ali RM, Ganesalingam $M$, Haleagrahara N. Hypoxia-inducible factor- $1 \alpha$ as a predictive marker in pre-eclampsia. Biomedical reports. 2013; 1(2):257-8 https://doi.org/10.3892/br.2012.44 PMid:24648931 PMCid:PMC3956219

20. Sastroasmoro S, Ismael S. Dasar-dasar metodologi penelitian klinis. Jakarta: Sagung Seto. 2011; 372.

21. Kimura C, Watanabe K, Iwasaki A, Mori T, Matsushita H, Shinohara K, Wakatsuki A. The severity of hypoxic changes and oxidative DNA damage in the placenta of early-onset preeclamptic women and fetal growth restriction. The Journal of Maternal-Fetal \& Neonatal Medicine. 2013; 26(5):491-6.

https://doi.org/10.3109/14767058.2012.733766 PMid:23035823

22. Rolfo A, Many A, Racano A, Tal R, Tagliaferro A, letta F, Wang $\mathrm{J}$, Post M, Caniggia I. Abnormalities in oxygen sensing define early and late onset preeclampsia as distinct pathologies. PloS one. 2010; 5(10):e13288. https://doi.org/10.1371/journal.pone.0013288 PMid:20967267 PMCid:PMC2953500

23. Davutoglu A, AkkayaFirat A, Ozel A, et al. Evaluation of maternal serum hypoxia inducible factor-1a, progranulin and syndecan-1 levels in pregnancies with early- and late-onset preeclampsia. J Matern Fetal Neonatal Med. 2018; 31(15):19761982. https://doi.org/10.1080/14767058.2017.1333098 PMid:28574293 